\title{
A Comparative Study of Selected Factors of University Education in Kenya and India: Opinions of the Kenyan University Students in Andhra Pradesh State
}

\author{
Jacob Mbijjiwe ${ }^{1}$, R.M. Pallavi ${ }^{2}$, Mcdonald .M. Kalama ${ }^{3}$,Emmanuel Member ${ }^{4}$ \\ ${ }^{\text {I}(B u s i n e s s ~ M a n a g e m e n t, ~ U C C B M, ~ O s m a n i a ~ U n i v e r s i t y, ~ H y d e r a b a d, ~ I n d i a) ~}$ \\ ${ }^{2}$ (Business Management, UCCBM, Osmania University, Hyderabad, India) \\ ${ }^{3}$ (Business Management, UCCBM, Osmania University, Hyderabad, India) \\ ${ }^{4}$ (Psychology, Arts College, Osmania University, Hyderabad, India)
}

\begin{abstract}
African countries have for many years been unable to offer satisfactory education service to their populace. This has lead to stiff competition for the few available government sponsored vacancies which has resulted to unnecessary inflated cost of education hence knocking out the poor from the vital service. To help open up for more opportunities a study was conducted comparing some factors of university education in Kenya and India and specifically Andhra Pradesh State. The study aimed at bringing to the attention of Kenyans parents the available university education in India. The study was meant to be a census study of all the registered 61 Kenyan university students in A.P. but eventually it was 49 who were available to fill the questionnaire giving a sample size of $80 \%$ for study. Data analyses was done by use of Statistical Package for Social Sciences (SPSS) version 20 and presentation was by use of tables, pie charts and graphs. The study focused on academic, financial and social factors that could discourage Kenyan students from enrolling in the Indian universities. The study revealed that the course content of the Indian universities were more highly rated by Kenyan students. The other facilities like Laboratories, books, Libraries and Computers are more available in India than in Kenyan universities. The social amenities and cultural factors were rated lower in India than Kenya and likely to cause discouragement to enrolment. The study made recommendations that;

- Kenyan universities need to target core factors when pricing for their courses to ensure affordability, especially to the poor.

- There should be more heightened publicity about the cost and content differentiation between the two countries.

- There is need to evaluate the course content of some of the courses offered in Kenyan universities.

- There is need for guidance to Kenyans going for study in India so as to pick courses that have better job opportunities and good international appeal.

- There is need for the Indian universities to improve on social amenities and adapt more open and interactive methods of instruction to attract more foreign students.

Key words: University Education, Financial Costs, Social Cultural Factors, India and Kenya.
\end{abstract}

\section{Introduction}

The Kenyan higher education system developed from Makerere Technical College which, from its inception in 1922 served the education needs of the three (3) countries in the East African region namely: Uganda, Tanganyika and Kenya. The Royal Technical College was set up in 1956 which later became The University of Nairobi in 1970, Kenya's first higher education institution. Moi University, Kenyatta and Egerton were next to be established as independent public Universities in the 1980s. Since then other public and private universities have come up in Kenya but what is very characteristic throughout this historical development is the insatiable demand for affordable and quality university education in Kenya. The prime and cheaper government sponsored slots have always left a huge percentage of qualified students out hence the need for other alternatives.

Private institutions and parallel programs within the public universities have come up to try and solve the problem but it has proved too expensive especially to the middle and lower income earners. Another alternative has been to seek for higher education service from out of the country with popular destinations being United States of America, Great Britain, Canada, South Africa, Australia and many other countries, but this once again is an option to the privileged in the society. India was a popular destination in the 1980s and 1990s but not currently, according to Kenya's High Commissioner to India Francis Kaberia, Kenya has some 3,500 students studying in India (The Times of India, 2013 ). A good number of these students are sponsored by various schemes like Indian Council for Cultural Relations (ICCR) but most are privately sponsored. What is 
very clear is that the Kenyan education system has borrowed a lot from the Indian due to the long historical ties and having shared similar colonial background.

The element of cost has always been the reason for the few who have turned to India but it is still not well known to many Kenyans that Indian as an education destination can be up to $50 \%$ cheaper than Kenya for the same quality of some university education degrees if not better. Most Kenyans when making choices base their decisions on education costs of Western countries which is up to ten times more than India. India has largely been lauded for it quality of education at very cheap rates especially in IT, Law, Engineering, Medicine and Commerce to mention but a few. The emanating low cost is a result of targeting the core function of institutions and leaving out what is not core like accommodation and meals. The cost of living for foreign students, which basically includes food, transport, accommodation and health is far too low as compared to Kenya.

The cultural factor has always been the other bone of contention with many Kenyans feeling that the Indian and Kenyan way of living are in compatible. As much as that is right to some degree, the Indian culture is such that there is a very low level of violence and criminality as compared to anywhere else in the world. Religious and cultural differences are never an issue to deter a determined and focused student in India. Moreover, the Southern India where this research was done is a multi-religious region with Hindu, Islam and Christianity taking the centre stage in such a way that any Kenya there will get a place of worship conveniently. Generally the people of India are a much closed society who have little to do with visitors. All in all the Indian way of life does not in any way affect the foreigners especially those who do not bother to poke into their privacy.

\section{STATEMENT OF THE PROBLEM}

This research is founded on the premise that the cost of education in Kenya could be much higher than it is in Indian. Most parents are ignorant of that fact and in some cases and courses could be paying up to four times higher in gross cost per year.

The study further presumes that in India course coverage and content are more enhanced due to the level of technology and specialization more especially to students interested in engineering, IT (Information Technology), LLB (Bachelors in Law), Bsc.(microbiology, pharmacy \& nursing) courses. Students in these areas are likely to be exposed to more computers, libraries and well laboratories. Research and practical works could be more enhanced than the case is in Kenya.

The teaching staff in India is far ahead of Kenya in terms of experience, qualification and the numbers especially when it comes to $\mathrm{PhD}$ holders. India has a rich history of University education unlike Kenyan whose university education is slightly over forty years.

The enrollment of students per class in Kenya is very high in comparison to the physical facilities making it difficult to guarantee access to quality education. The story in Indian higher educational institutions is different because it is rare for a class to go beyond forty students in whichever area. Access to text books is another area of advantage because India has many publishing firms giving rise to a variety of text books and also low cost editions.

The student per class is quite high in Kenya compared to India making it difficult for an effective student - teacher interaction. However, in India on the other hand, the cultural and social domains could limit the class room interaction to mere dictation. The foreign students in the classrooms improve the level of interaction remarkably.

Both countries being colonies of Great Britain enjoy the distinction of having English as their language of instruction in most of the institutions which means an easier way of Kenya students getting into the system.

The social and cultural factors in India have discouraged many potential students to India especially of Christian background, which should not be the case because there is a substantial Christian population in India. Though security levels are very high, social and cultural factors can be irritating to new students but may not be a big issue since there is significantly less interaction with the local people.

\section{JUSTIFICATION OF STUDY}

Education being an investment today there is every reason why everybody should get the best knowledge on where to invest in education for best results at a cheaper cost. That is one reason why this study is necessary.

This study will give advice and suggestion on improving the education system in Kenya.

\section{OBJECTIVES OF THE STUDY.}

1. To assess and compare the cost differences between university education in Kenya and India.

2. To assess and compare the course content and depth of university education in Kenya and India.

3. To assess and compare the facilities available for university education in Kenya and India 
4. To assess and compare the university classroom environment in Kenya and India.

5. To assess and compare the effect of cultural factors to students between Kenya and India.

6. To give suggestion on how to improve university education in Kenya.

\section{HYPOTHESIS}

Hypotheses 1.

Ho: There is no significance difference between the cost of university education in Kenya and India.

Hypotheses 2.

Ho: There is no significant difference between the university course content in Kenya and India.

Hypotheses 3.

Ho: There is no significance variation in opinions of the respondents on the University facilities available in Kenya and India.

Hypotheses 4.

Ho: There is no significance variation in opinions of respondents on classroom environment in Kenya and India. Hypotheses 5.

Ho: There is no significant variation in opinions of respondents on cultural and environmental factors in Kenya and India.

\section{Review Of Related Literature}

The problem of cost as a limitation to access to quality higher education was foreseen by Wandiga (1997) in his monograph on improving managerial effectiveness and wondered for how long the capping of the maximum number of students winning university slots will continue. The obvious alternative is looking East.

In the Indian context, a paper by Kaul S. (2006), on seizing the opportunities internationally addresses issues to do with quality of higher education, accreditation of institutions, increased funding and shift to knowledge based economies all in an effort to capture the global market where education is taken as one of the main ingredients.

Boit and Kipkoech (2012), both senior staff in Moi University, in their study on cost implications of liberalization of higher education in Kenya which took them through the historical development of Kenyan university realized that there is a huge challenge towards access to education due to its high cost. They recommend Open and Distance Education (ODE) mode and other alternative to help surmount the challenge. This is where this study can assist in offering the Indian context as an alternative.

Enhancing the quality and accessibility of higher education through the use of Information and Communication, a paper by Hattangdi A. and Prof. A. Ghosh (2009) paint a picture which portray India as beyond the teething challenges of ICT in education and for that reason Kenyan students can only take advantage of that. The findings are highly collaborated by Parida, S (2010) in the study tiltled "utilization of information and communication technology (ICT) tools by staff and students in universities".

A study by Christopher Colclough et al (2010) titled The Impact of aid on education policy in India and Kenya reveals a glaring lack of policy direction in Kenya which could be the reason for the high cost of Education in all levels and lack of direction to cheaper destinations.

In the current development phase a computer is everything, Okwakol (2008) points out that a computer today is a notebook, textbook, dictionary, school bag and a storage for the educational material. Kenyan universities are still miles behind Indian institutions as far as this is concerned.

Although statistics from online encyclopedia NationMaster.com ranks Kenya better than India in indices like gross literacy rates, school completion rates, female enrolment, girls dropout rates, it ranks poor than India in financial and education cost related indices like government spending in education, percentage of GDP, and gross public spending on education. Munene (2009) declares that the East African trend of privatization of university education mirrors less of what is common in worlds with a long history of private universities. The bottom line is the cost is totally prohibitive to middle and low income groups.

Gudo et al (2011) in their study on university expansion and its impact on quality collected data from May to November 2010 from a sample of 502 university students and 127 lecturers using structured questionnaires. They found out that public universities did not have the necessary physical facilities to effectively offer service to its current student body. These findings are highly collaborated by Oanda et al (2008) in their paper on privatization of education in Kenya.

A study by UNESCO (2011) on school based sexuality education programs in six countries namely; Kenya, Estonia, Nigeria, India, Indonesia and the Netherlands revealed that the cost of implementing the program per student in Kenya was about three times higher than it was in India.

To summarize what James Tooley (2009) has in the article titled "Low cost private schools as part of the solution for education for all" and his book, "The Beautiful Tree: a personal journey into how the world's poorest people are educating themselves", there is a possibility of accessing high quality education through low cost private institutions as compared to public institutions. This conclusion was reached after a wide empirical 
research in Asia, Africa and Latin America. The study builds a case for the need of Kenyan parents seeking alternative and cheaper university education in Asia and India to be specifically.

Eshiwani (2009), Mutisya (2010) and Burungi (2006) have all addressed the low quality of education in Kenyan universities due to a poor evaluation system lacking in external standardization of examinations.

The University Grant Commission (2008), New Delhi lists the institutions as having a student teacher ratio (STR) of about 33 and PhD and M.Phil composition of about $43 \%$ of the universities teaching staff. This is far too impressive rates compared to the enrolment ratios in Kenya.

\section{Methodology}

This study is descriptive in nature but on some issues employed evaluative techniques to make conclusive judgments.

The questionnaire employed 5-point Likert scale ranging from 1 for strongly disagree up to 5 for strongly agree to get the respondents opinions.

The respondents were picked on convenience bases from all the Kenyan students in Andhra Pradesh (A.P) state, attending various courses. A total of 49 out of 61 registered students responded to the questionnaire. This represents a sample size of $80 \%$.

\section{Characteristics of Respondents}

\section{Research Data Analysis}

Courses of study

\begin{tabular}{|l|l|l|l|}
\hline & Frequency & Percent & Cumulative Percent \\
\hline Valid B.Com & 13 & 26.5 & 26.5 \\
\hline B.Arts & 4 & 8.2 & 34.7 \\
\hline B.Sc & 7 & 14.3 & 49.0 \\
\hline B.Eng & 11 & 22.4 & 71.4 \\
\hline LLB & 3 & 6.1 & 77.6 \\
\hline Masters & 10 & 20.4 & 98.0 \\
\hline PhD & 1 & 2.0 & 100.0 \\
\hline Total & 49 & 100.0 & \\
\hline
\end{tabular}

The data is clear that Bachelor of Commerce (B,Com), Bachelor of Engineering (B.Eng), Bachelor of Science in Computer Science (B.Sc) and Masters programs are the most popular areas of study by Kenyans in India

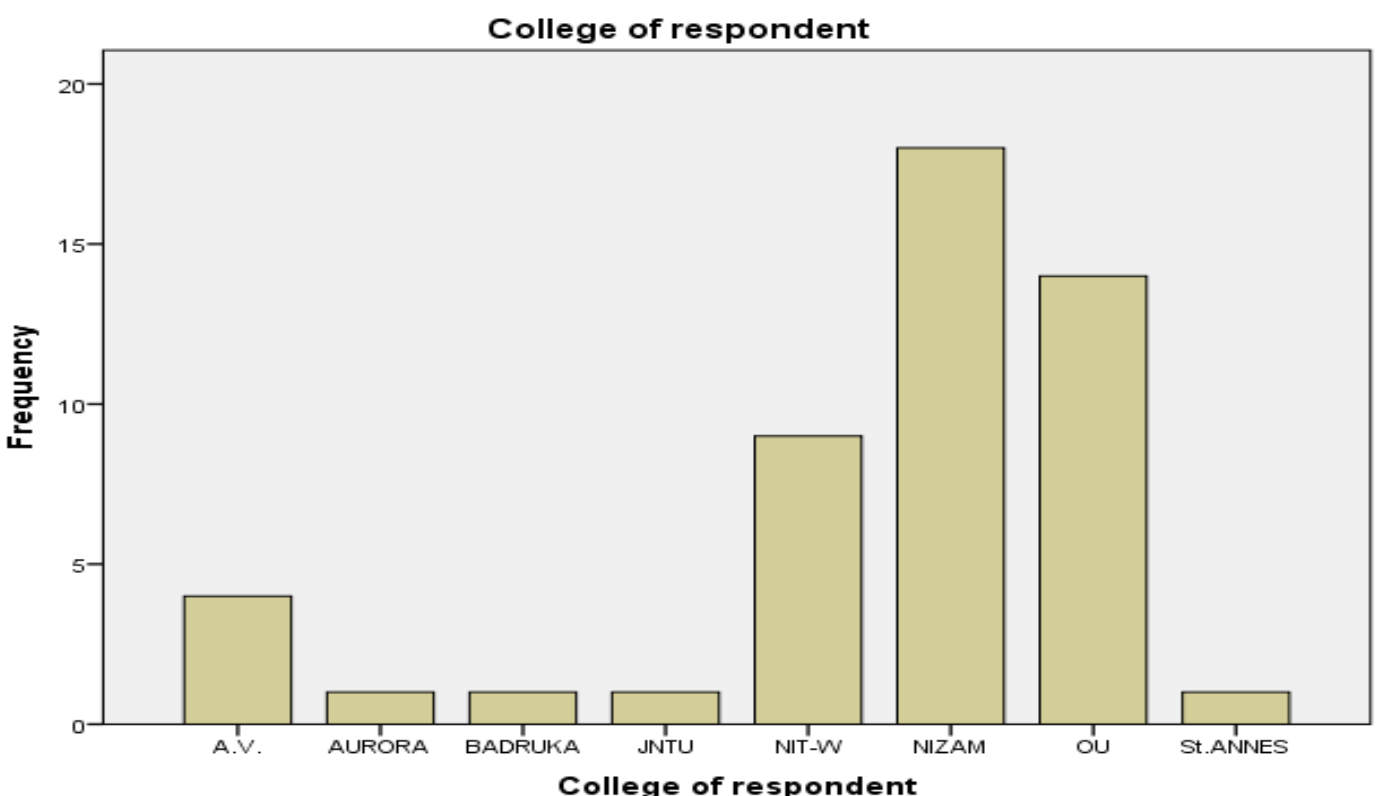

The respondents were basically found in 8 University colleges with the majority found in Nizam, Main Campuses of Osmania University (OU), and National Institute of Technology-Warangal (NIT-W). The other colleges recorded small number of students.

Sex of Respondents 


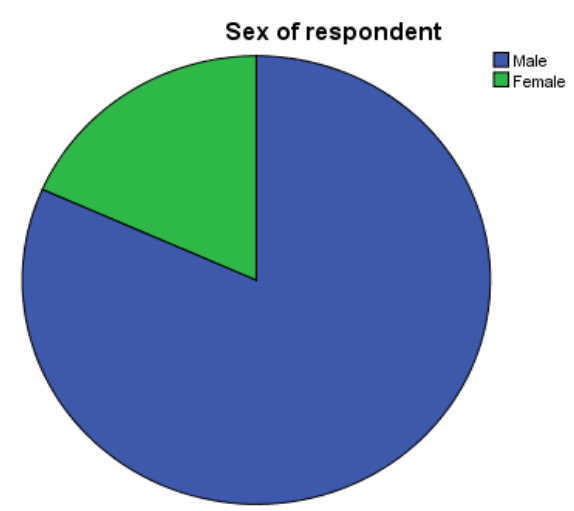

By sex the Males represented $81.6 \%$ of respondents while the Females were $18.4 \%$ of the respondents. This is a true representation of the proportions of the population of Kenyans in Andhra Pradesh State.

\section{Respondents' Opinions on Various Aspects of the Courses}

Course Content and syllabi coverage

The respondents' opinions on course content and syllabi coverage were analyzed against their courses and revelation summarized as;

Opinions on course content and coverage

\begin{tabular}{|c|c|c|c|c|c|c|}
\hline \multicolumn{2}{|c|}{ Course of study } & \multirow{2}{*}{$\begin{array}{l}\text { Content width } \\
2.62 \\
13 \\
1.044\end{array}$} & \multirow{2}{*}{$\begin{array}{l}\text { Content depth } \\
2.92 \\
13 \\
1.256 \\
\end{array}$} & \multirow{2}{*}{$\begin{array}{l}\text { Syllabi coverage } \\
2.62 \\
13 \\
1.193\end{array}$} & \multirow{2}{*}{\begin{tabular}{|l|}
$\begin{array}{l}\text { Learning } \\
\text { activities }\end{array}$ \\
2.54 \\
13 \\
1.127 \\
\end{tabular}} & \multirow{2}{*}{$\begin{array}{l}\text { Short courses } \\
2.69 \\
13 \\
1.797\end{array}$} \\
\hline B.Com & $\begin{array}{l}\text { Mean } \\
\mathrm{N} \\
\text { Std. Deviation }\end{array}$ & & & & & \\
\hline B.Arts & $\begin{array}{l}\text { Mean } \\
\mathrm{N} \\
\text { Std. Deviation }\end{array}$ & $\begin{array}{l}3.50 \\
4 \\
.577\end{array}$ & $\begin{array}{l}4.00 \\
4 \\
.000\end{array}$ & $\begin{array}{l}3.75 \\
4 \\
.500 \\
\end{array}$ & $\begin{array}{l}3.25 \\
4 \\
1.258\end{array}$ & \begin{tabular}{|l|}
3.25 \\
4 \\
1.708 \\
\end{tabular} \\
\hline B.Sc & $\begin{array}{l}\text { Mean } \\
\mathrm{N} \\
\text { Std. Deviation }\end{array}$ & $\begin{array}{l}3.86 \\
7 \\
.900\end{array}$ & $\begin{array}{l}3.57 \\
7 \\
1.134\end{array}$ & $\begin{array}{l}3.29 \\
7 \\
.756\end{array}$ & $\begin{array}{l}3.14 \\
7 \\
1.345 \\
\end{array}$ & $\begin{array}{l}4.57 \\
7 \\
.787 \\
\end{array}$ \\
\hline B.Eng & $\begin{array}{l}\text { Mean } \\
\mathrm{N} \\
\text { Std. Deviation }\end{array}$ & $\begin{array}{l}4.73 \\
11 \\
.467\end{array}$ & $\begin{array}{l}4.18 \\
11 \\
.982\end{array}$ & $\begin{array}{l}3.73 \\
11 \\
.905\end{array}$ & $\begin{array}{l}4.00 \\
11 \\
.894 \\
\end{array}$ & $\begin{array}{l}3.27 \\
11 \\
1.737 \\
\end{array}$ \\
\hline LLB & $\begin{array}{l}\text { Mean } \\
\mathrm{N} \\
\text { Std. Deviation }\end{array}$ & $\begin{array}{l}4.00 \\
3 \\
.000\end{array}$ & $\begin{array}{l}4.33 \\
3 \\
.577\end{array}$ & $\begin{array}{l}3.00 \\
3 \\
1.000\end{array}$ & $\begin{array}{l}2.67 \\
3 \\
.577\end{array}$ & $\begin{array}{l}2.00 \\
3 \\
.000\end{array}$ \\
\hline Masters & $\begin{array}{l}\text { Mean } \\
\mathrm{N} \\
\text { Std. Deviation }\end{array}$ & $\begin{array}{l}4.50 \\
10 \\
.850\end{array}$ & $\begin{array}{l}3.80 \\
10 \\
.789\end{array}$ & $\begin{array}{l}3.60 \\
10 \\
1.075 \\
\end{array}$ & $\begin{array}{l}3.80 \\
10 \\
.422 \\
\end{array}$ & $\begin{array}{l}4.30 \\
10 \\
.823\end{array}$ \\
\hline $\mathrm{PhD}$ & $\begin{array}{l}\text { Mean } \\
\mathrm{N} \\
\text { Std. Deviation }\end{array}$ & $\begin{array}{l}2.00 \\
1\end{array}$ & $\begin{array}{l}2.00 \\
1\end{array}$ & $\begin{array}{l}2.00 \\
1\end{array}$ & $\begin{array}{l}2.00 \\
1\end{array}$ & $\begin{array}{l}2.00 \\
1\end{array}$ \\
\hline Total & $\begin{array}{l}\text { Mean } \\
\mathrm{N} \\
\text { Std. Deviation }\end{array}$ & $\begin{array}{l}3.80 \\
49 \\
1.154\end{array}$ & $\begin{array}{l}3.63 \\
49 \\
1.093\end{array}$ & $\begin{array}{l}3.27 \\
49 \\
1.056 \\
\end{array}$ & $\begin{array}{l}3.27 \\
49 \\
1.114 \\
\end{array}$ & $\begin{array}{l}3.41 \\
49 \\
1.580 \\
\end{array}$ \\
\hline
\end{tabular}

All the courses were rated highly with an index of above 3.5 in content width, content depth, learning activities and syllabi coverage, with an exception of B.Com and Doctor of Philosophy (Ph.D) which were around 2.5 in rating index. Learning activities and availability of short courses also attracted a low score in LLB (Bachelors in Law). The mean index for the five categories are around and above an index of 3.5 implying on average the content and syllabus coverage in India is rated higher than it is in Kenyan Universities. 
ANOVA Table: significance of difference in course content

\begin{tabular}{|c|c|c|c|c|c|c|c|}
\hline & & & $\begin{array}{l}\text { Sum of } \\
\text { Squares }\end{array}$ & $\mathrm{df}$ & Mean Square & $\mathrm{F}$ & Sig. \\
\hline $\begin{array}{l}\text { Content width } * \text { Course of } \\
\text { study }\end{array}$ & $\begin{array}{l}\text { Between Groups } \\
\text { Within Groups } \\
\text { Total }\end{array}$ & (Combined) & $\begin{array}{l}36.343 \\
27.616 \\
63.959\end{array}$ & $\begin{array}{l}6 \\
42 \\
48\end{array}$ & $\begin{array}{l}6.057 \\
.658\end{array}$ & 9.212 & .000 \\
\hline $\begin{array}{l}\text { Content depth } * \text { Course of } \\
\text { study }\end{array}$ & $\begin{array}{l}\text { Between Groups } \\
\text { Within Groups } \\
\text { Total }\end{array}$ & (Combined) & $\begin{array}{l}14.847 \\
42.540 \\
57.388 \\
\end{array}$ & $\begin{array}{l}6 \\
42 \\
48\end{array}$ & $\begin{array}{l}2.475 \\
1.013\end{array}$ & 2.443 & .041 \\
\hline $\begin{array}{l}\text { Syllabi coverage * Course } \\
\text { of study }\end{array}$ & $\begin{array}{l}\text { Between Groups } \\
\text { Within Groups } \\
\text { Total }\end{array}$ & (Combined) & $\begin{array}{l}11.714 \\
41.837 \\
53.551\end{array}$ & $\begin{array}{l}6 \\
42 \\
48\end{array}$ & $\begin{array}{l}1.952 \\
.996\end{array}$ & 1.960 & .093 \\
\hline $\begin{array}{l}\text { Learning activities * } \\
\text { Course of study }\end{array}$ & $\begin{array}{l}\text { Between Groups } \\
\text { Within Groups } \\
\text { Total }\end{array}$ & (Combined) & $\begin{array}{l}18.446 \\
41.105 \\
59.551 \\
\end{array}$ & $\begin{array}{l}6 \\
42 \\
48 \\
\end{array}$ & $\begin{array}{l}3.074 \\
.979\end{array}$ & 3.141 & .012 \\
\hline $\begin{array}{l}\text { Short courses } * \text { Course of } \\
\text { study }\end{array}$ & $\begin{array}{l}\text { Between Groups } \\
\text { Within Groups } \\
\text { Total }\end{array}$ & (Combined) & $\begin{array}{l}32.321 \\
87.515 \\
119.837\end{array}$ & $\begin{array}{l}6 \\
42 \\
48\end{array}$ & $\begin{array}{l}5.387 \\
2.084\end{array}$ & 2.585 & .032 \\
\hline
\end{tabular}

ANOVA test for significance in difference of opinions was done. This test sought to accept or reject the hypothesis that "there is no significance difference in content and syllabi coverage between Kenya and India". The hypothesis is REJECTED thus the difference is significant in all categories except syllabus coverage. This implies India is significantly better in many of the content aspects.

Opinions on General University Facilities

\begin{tabular}{|c|c|c|c|c|c|}
\hline \multicolumn{2}{|c|}{ Course of study } & \multirow{2}{*}{$\frac{\text { Labs and Comps }}{2.77}$} & \multirow{2}{*}{ Available text books } & \multirow{2}{*}{ Equiped libraries } & Social amenities \\
\hline & Mean & & & & 2.54 \\
\hline B.Com & $\mathrm{N}$ & 13 & 13 & 13 & 13 \\
\hline & Std. Deviation & 1.166 & .801 & 1.127 & 1.050 \\
\hline & Mean & 2.75 & 3.25 & 3.25 & 2.00 \\
\hline B.Arts & $\begin{array}{l}\mathrm{N} \\
\text { Std. Deviation }\end{array}$ & $\begin{array}{l}4 \\
.957\end{array}$ & $\begin{array}{l}4 \\
1.500\end{array}$ & $\begin{array}{l}4 \\
1.258\end{array}$ & $\begin{array}{l}4 \\
1.155\end{array}$ \\
\hline & Mean & 3.86 & 4.86 & 4.29 & 2.43 \\
\hline B.Sc & $\begin{array}{l}\mathrm{N} \\
\text { Std. Deviation }\end{array}$ & $\begin{array}{l}7 \\
1.215\end{array}$ & $\begin{array}{l}7 \\
.378\end{array}$ & $\begin{array}{l}7 \\
.756\end{array}$ & $\begin{array}{l}7 \\
1.134\end{array}$ \\
\hline & Mean & 4.00 & 4.45 & 3.91 & 2.45 \\
\hline B.Eng & $\begin{array}{l}\mathrm{N} \\
\text { Std. Deviation }\end{array}$ & $\begin{array}{l}11 \\
1.183\end{array}$ & $\begin{array}{l}11 \\
.934\end{array}$ & & $\begin{array}{l}11 \\
1.293\end{array}$ \\
\hline LLB & $\begin{array}{l}\text { Mean } \\
\mathrm{N} \\
\text { Std. Deviation }\end{array}$ & $\begin{array}{l}2.33 \\
3 \\
1.155\end{array}$ & $\begin{array}{l}4.67 \\
3 \\
.577\end{array}$ & $\begin{array}{l}4.33 \\
3 \\
1.155\end{array}$ & $\begin{array}{l}1.67 \\
3 \\
.577\end{array}$ \\
\hline Masters & $\begin{array}{l}\text { Mean } \\
\mathrm{N} \\
\text { Std. Deviation }\end{array}$ & $\begin{array}{l}4.40 \\
10 \\
.699\end{array}$ & $\begin{array}{l}4.60 \\
10 \\
1.265\end{array}$ & $\begin{array}{l}4.50 \\
10 \\
.707\end{array}$ & $\begin{array}{l}2.40 \\
10 \\
.843\end{array}$ \\
\hline $\mathrm{PhD}$ & $\begin{array}{l}\text { Mean } \\
\mathrm{N} \\
\text { Std. Deviation }\end{array}$ & $\begin{array}{l}3.00 \\
1\end{array}$ & $\begin{array}{l}5.00 \\
1\end{array}$ & $\begin{array}{l}5.00 \\
1\end{array}$ & $\begin{array}{l}2.00 \\
1\end{array}$ \\
\hline Total & $\begin{array}{l}\text { Mean } \\
\mathrm{N} \\
\text { Std. Deviation }\end{array}$ & $\begin{array}{l}3.51 \\
49 \\
1.244\end{array}$ & $\begin{array}{l}4.39 \\
49 \\
.996\end{array}$ & $\begin{array}{l}3.71 \\
49 \\
1.258\end{array}$ & $\begin{array}{l}2.37 \\
49 \\
1.035\end{array}$ \\
\hline
\end{tabular}

In terms of general university facilities all the courses rated availability of books very highly and high on Laboratories, computer rooms and Libraries as compared to Kenyan Universities. There was an agreement across the courses that the social amenities are poor rated compared to the Kenyan Universities. Significantly absent in India were the many college buses, clean cut lawns and posh hostels which are characteristic of Kenya Public Universities.

ANOVA Table on significance in difference in Facilities

\begin{tabular}{|c|c|c|c|c|c|c|}
\hline & & $\begin{array}{l}\text { Sum of } \\
\text { Squares }\end{array}$ & $\mathrm{df}$ & $\begin{array}{l}\text { Mean } \\
\text { Square }\end{array}$ & $\mathrm{F}$ & Sig. \\
\hline $\begin{array}{l}\text { Labs and Comps * Course } \\
\text { of study }\end{array}$ & $\begin{array}{l}\text { Between Groups } \quad \text { (Combined) } \\
\text { Within Groups } \\
\text { Total }\end{array}$ & $\begin{array}{l}25.263 \\
48.982 \\
74.245\end{array}$ & $\begin{array}{l}6 \\
42 \\
48\end{array}$ & $\begin{array}{l}4.211 \\
1.166\end{array}$ & 3.610 & .006 \\
\hline $\begin{array}{l}\text { Available text books * } \\
\text { Course of study }\end{array}$ & $\begin{array}{l}\text { Between Groups } \quad \text { (Combined) } \\
\text { Within Groups } \\
\text { Total }\end{array}$ & $\begin{array}{l}8.539 \\
39.093 \\
47.633\end{array}$ & $\begin{array}{l}6 \\
42 \\
48\end{array}$ & $\begin{array}{l}1.423 \\
.931\end{array}$ & 1.529 & .192 \\
\hline
\end{tabular}




\begin{tabular}{|lll|l|l|l|l|l|}
\hline \multirow{2}{*}{$\begin{array}{l}\text { Equiped libraries * Course } \\
\text { of study }\end{array}$} & $\begin{array}{l}\text { Between Groups (Combined) } \\
\text { Within Groups } \\
\text { Total }\end{array}$ & 30.515 & 6 & 5.086 & 4.696 & $\mathbf{. 0 0 1}$ \\
\hline \multirow{2}{*}{$\begin{array}{l}\text { Social ammenities * Course } \\
\text { of study }\end{array}$} & Between Groups (Combined) & 76.000 & 4.649 & 48 & 1.083 & & \\
& Within Groups & & 48.739 & 42 & 1.160 & & \\
& Total & 51.388 & 48 & & & \\
\hline
\end{tabular}

The hypothesis that "there is no significant difference in the facilities" was tested and REJECTED for Laboratories, Computer rooms and Libraries and ACCEPTED for books and social amenities. This implies there is a significant difference in Laboratories, Computer rooms and Libraries with India being more favourable to respondents. On books and social amenities, there was common consensus that text books were more cheaply and easily available than in Kenya. The respondents were for the opinion that social amenities were poor in a significant way.

Opinions on Class room Environment

\begin{tabular}{|c|c|c|c|c|c|}
\hline \multicolumn{2}{|c|}{ Course of study } & Class size & Students interaction & Lecturer instruction & $\begin{array}{l}\text { Language } \\
\text { instruction }\end{array}$ \\
\hline \multirow{3}{*}{ B.Com } & Mean & 2.62 & 2.46 & 2.54 & 1.69 \\
\hline & $\mathrm{N}$ & 13 & 13 & 13 & 13 \\
\hline & Std. Deviation & 1.261 & 1.198 & 1.391 & .480 \\
\hline \multirow{3}{*}{ B.Arts } & Mean & 3.25 & 2.25 & 2.00 & 1.50 \\
\hline & & 4 & & 4 & 4 \\
\hline & Std. Deviation & 1.258 & .957 & 1.155 & 1.000 \\
\hline \multirow{3}{*}{ B.Sc } & Mean & 3.71 & 1.43 & 2.57 & 1.71 \\
\hline & $\mathrm{N}$ & 7 & 7 & 7 & 7 \\
\hline & Std. Deviation & 1.113 & .535 & 1.397 & 1.113 \\
\hline \multirow{3}{*}{ B.Eng } & Mean & 4.36 & 2.18 & 2.64 & 2.18 \\
\hline & & 11 & 11 & 11 & 11 \\
\hline & Std. Deviation & .809 & 1.168 & 1.362 & .751 \\
\hline \multirow{3}{*}{ LLB } & Mean & 2.33 & 1.33 & 2.67 & 2.33 \\
\hline & & & & & \\
\hline & Std. Deviation & .577 & .577 & 1.155 & .577 \\
\hline \multirow{3}{*}{ Masters } & Mean & 3.90 & 2.20 & 3.10 & 1.80 \\
\hline & $\mathrm{N}$ & 10 & 10 & 10 & 10 \\
\hline & Std. Deviation & 1.101 & 1.135 & 1.101 & .919 \\
\hline \multirow[b]{2}{*}{$\mathrm{PhD}$} & Mean & 3.00 & 2.00 & 2.00 & 2.00 \\
\hline & $\begin{array}{l}\mathrm{N} \\
\text { Std. Deviation }\end{array}$ & 1 & 1 & 1 & 1 \\
\hline \multirow{3}{*}{ Total } & Mean & 3.47 & 2.10 & 2.63 & 1.86 \\
\hline & $\mathrm{N}$ & 49 & 49 & 49 & 49 \\
\hline & Std. Deviation & 1.243 & 1.065 & 1.253 & .791 \\
\hline
\end{tabular}

On the classroom environment, respondents felt that these factors were not well enhanced in comparison to Kenyan Universities. On class size, except B.Com and LLB, the other courses felt the class size was conducive for study. On closer scrutiny it was clear that even those two which registered low opinion the size was very conducive but characterized with a huge absence of students in most of the lessons. On the students' interaction, lecturers' instruction and language of instruction, the respondents felt that they were lower in India compared to Kenya. This is a very characteristic phenomenon in all of India due to the nature of the cultural conditions which make it a significantly closed society.

ANOVA Table on significance of variation in responses

\begin{tabular}{|c|c|c|c|c|c|c|}
\hline & & $\begin{array}{ll}\text { Sum } & \text { of } \\
\text { Squares } & \\
\end{array}$ & $\mathrm{df}$ & $\begin{array}{l}\text { Mean } \\
\text { Square }\end{array}$ & $\mathrm{F}$ & Sig. \\
\hline $\begin{array}{l}\text { Class size } * \text { Course of } \\
\text { study }\end{array}$ & $\begin{array}{l}\text { Between Groups (Combined) } \\
\text { Within Groups } \\
\text { Total }\end{array}$ & $\begin{array}{l}24.836 \\
49.368 \\
74.204 \\
\end{array}$ & $\begin{array}{l}6 \\
42 \\
48 \\
\end{array}$ & $\begin{array}{l}4.139 \\
1.175\end{array}$ & 3.522 & .007 \\
\hline $\begin{array}{l}\text { Students interaction } * \\
\text { Course of study }\end{array}$ & $\begin{array}{l}\text { Between Groups (Combined) } \\
\text { Within Groups } \\
\text { Total }\end{array}$ & $\begin{array}{l}6.892 \\
47.598 \\
54.490\end{array}$ & $\begin{array}{l}6 \\
42 \\
48\end{array}$ & $\begin{array}{l}1.149 \\
1.133\end{array}$ & 1.014 & .430 \\
\hline $\begin{array}{l}\text { Lecturer instruction } * \\
\text { Course of study }\end{array}$ & $\begin{array}{l}\text { Between Groups (Combined) } \\
\text { Within Groups } \\
\text { Total }\end{array}$ & $\begin{array}{l}4.331 \\
71.057 \\
75.388\end{array}$ & $\begin{array}{l}6 \\
42 \\
48\end{array}$ & $\begin{array}{l}.722 \\
1.692\end{array}$ & .427 & .857 \\
\hline $\begin{array}{l}\text { Language of instruction } * \\
\text { Course of study }\end{array}$ & $\begin{array}{l}\text { Between Groups (Combined) } \\
\text { Within Groups } \\
\text { Total }\end{array}$ & $\begin{array}{l}2.899 \\
27.101 \\
30.000\end{array}$ & $\begin{array}{l}6 \\
42 \\
48\end{array}$ & $\begin{array}{l}.483 \\
.645\end{array}$ & .749 & .614 \\
\hline
\end{tabular}


On testing of the hypothesis that, "there is no significant variation in the respondents opinion on the classroom environment", it was REJECTED for class size and ACCEPTED for the other factors implying there was no significant variation hence respondents were unanimously in agreement to the opinions.

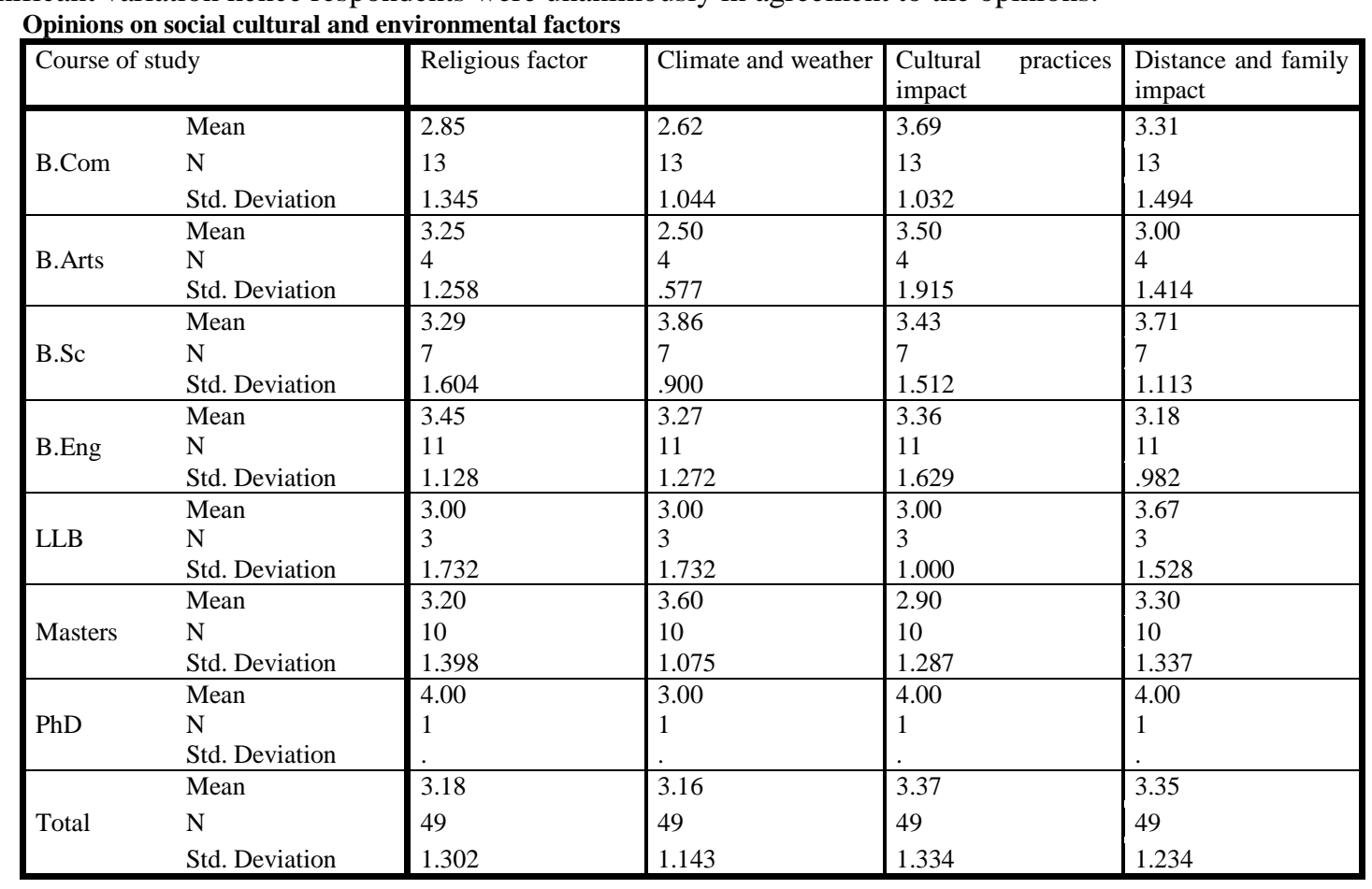

In terms of cultural and environmental factors all the courses had respondents feeling that these factors play a discouraging role towards Kenyans taking places in Indian universities. Distance from home and the cultural practices had the greatest average impact while the religious and climate factors followed closely. But of worth noting is all the factors portrayed a relatively high standard deviation possibly because of the diversity in back ground of respondents and their personal feelings.

ANOVA Table on significance of differences on opinions on culture

\begin{tabular}{|c|c|c|c|c|c|c|c|}
\hline & & & $\begin{array}{|lr|}\begin{array}{l}\text { Sum } \\
\text { Squares }\end{array} & \text { of } \\
\end{array}$ & $d f$ & Mean Square & $\mathrm{F}$ & Sig. \\
\hline $\begin{array}{l}\text { Religious factor } * \text { Course } \\
\text { of study }\end{array}$ & $\begin{array}{l}\text { Between Groups } \\
\text { Within Groups } \\
\text { Total }\end{array}$ & (Combined) & $\begin{array}{l}3.149 \\
78.198 \\
81.347 \\
\end{array}$ & $\begin{array}{l}6 \\
42 \\
48 \\
\end{array}$ & $\begin{array}{l}.525 \\
1.862\end{array}$ & .282 & .942 \\
\hline $\begin{array}{l}\text { Climate and weather * } \\
\text { Course of study }\end{array}$ & $\begin{array}{l}\text { Between Groups } \\
\text { Within Groups } \\
\text { Total }\end{array}$ & (Combined) & $\begin{array}{l}11.178 \\
51.516 \\
62.694 \\
\end{array}$ & $\begin{array}{l}6 \\
42 \\
48 \\
\end{array}$ & $\begin{array}{l}1.863 \\
1.227\end{array}$ & 1.519 & 196 \\
\hline $\begin{array}{l}\text { Cultural practices impact } \\
* \text { Course of study }\end{array}$ & $\begin{array}{l}\text { Between Groups } \\
\text { Within Groups } \\
\text { Total }\end{array}$ & (Combined) & $\begin{array}{l}4.459 \\
80.929 \\
85.388 \\
\end{array}$ & $\begin{array}{l}6 \\
42 \\
48 \\
\end{array}$ & $\begin{array}{l}.743 \\
1.927\end{array}$ & .386 & .884 \\
\hline $\begin{array}{l}\text { Distance and family } \\
\text { impact * Course of study }\end{array}$ & $\begin{array}{l}\text { Between Groups } \\
\text { Within Groups } \\
\text { Total }\end{array}$ & (Combined) & $\begin{array}{l}2.501 \\
70.601 \\
73.102\end{array}$ & $\begin{array}{l}6 \\
42 \\
48\end{array}$ & $\begin{array}{l}.417 \\
1.681\end{array}$ & .248 & .957 \\
\hline
\end{tabular}

On testing the hypothesis that, there is no significant variation on respondents' opinions on cultural and environmental factors, all the factors had the hypothesis accepted. This implies that the opinions were in high agreement and even though the standard deviation was relatively high it was not significant. 
Comparative Costs of Tuition Fees in Andhra Pradesh and Kenya

\begin{tabular}{|l|l|l|l|l|l|}
\hline $\begin{array}{l}\text { Course of } \\
\text { study }\end{array}$ & $\begin{array}{l}\text { Total Tuition Fees in } \\
\text { A.P. (Rupees) }\end{array}$ & N & $\begin{array}{l}\text { Total Tuition Fees in } \\
\text { A.P. (KShs) }\end{array}$ & $\begin{array}{l}\text { Average Tuition in } \\
\text { Kenya } \\
\text { Kshs) }\end{array}$ & $\begin{array}{l}\text { Return Air Ticket } \\
\text { Kshs) }\end{array}$ \\
\hline B.Com & $\mathbf{9 3 , 9 2 3}$ & $\mathbf{1 3}$ & $\mathbf{1 3 9 , 9 6 2 / =}$ & $\mathbf{5 6 0 , 0 0 0 / =}$ & $\mathbf{6 0 , 0 0 0 / =}$ \\
\hline B.Arts & $\mathbf{6 5 , 4 3 7}$ & $\mathbf{4}$ & $\mathbf{9 1 , 2 4 2 / =}$ & $\mathbf{4 8 0 , 0 0 0 / =}$ & $\mathbf{6 0 , 0 0 0 / =}$ \\
\hline B.Sc & $\mathbf{9 6 , 8 5 7}$ & $\mathbf{7}$ & $\mathbf{1 3 5 , 0 5 3 / =}$ & $\mathbf{6 2 0 , 0 0 0 / =}$ & $\mathbf{6 0 , 0 0 0 / =}$ \\
\hline B.Eng & $\mathbf{7 2 0 , 0 0 0}$ & $\mathbf{1 1}$ & $\mathbf{1 , 0 0 3 , 9 3 9 / =}$ & $\mathbf{1 , 0 5 0 , 0 0 0 / =}$ & $\mathbf{6 0 , 0 0 0 / =}$ \\
\hline LLB & $\mathbf{4 0 6 , 6 6 6}$ & $\mathbf{3}$ & $\mathbf{5 6 7 , 0 3 8 / =}$ & $\mathbf{7 6 0 , 0 0 0 / =}$ & $\mathbf{6 0 , 0 0 0 / =}$ \\
\hline Masters & $\mathbf{2 1 7 , 0 0 0}$ & $\mathbf{1 0}$ & $\mathbf{3 0 2 , 5 7 6} /=$ & $\mathbf{4 4 0 , 0 0 0 / =}$ & $\mathbf{6 0 , 0 0 0 / =}$ \\
\hline PhD & $\mathbf{6 0 0 , 0 0 0}$ & $\mathbf{1}$ & $\mathbf{8 3 6 , 6 1 6 / =}$ & $\mathbf{1 0 0 0 , 0 0 0 / =}$ & $\mathbf{6 0 , 0 0 0 / =}$ \\
\hline Total & & $\mathbf{4 9}$ & & & \\
\hline
\end{tabular}

On comparative total tuition cost for the entire course, the Kenyan tuition fees is significantly higher in all the courses except for Engineering courses which is roughly same as for Kenyan Universities. Bachelors in Commerce and Arts are significantly higher in Kenya at 4 times the fees in India with Masters, PhD and Bachelor in Law slightly higher but not the level of Kenyan Universities.

\section{Findings And Discussions}

It is evident that the courses that student opt for in India are basically the same courses that are very popular in Kenya like Commerce, Computer Science, Law and Engineering. Except in Engineering all the others are accessible at a much lower cost. The respondents also rated content and facilities better in India than Kenya.

May be due to culture related fears the population of female Kenyan students in India is low. At a meager $18 \%$ this proportion is too low compared to about $40 \%$ of the female enrolment in Kenyan universities. This is a clear testimony to parents feeling uncertain about some issues related to higher education in India.

On course contents, it is clear that India is rated better both in the depth and the learning activities involved. The student also enjoy the advantage of accessing other courses outside their specialization within the colleges and sometimes privately. There was discontent on syllabus coverage which is not very different from what happens in Kenya where once a course outline is issued it becomes the duty of the student to search for the knowledge even outside what the lecturer covered.

In terms of facilities provision in the universities there was a mixed reaction with between $75 \%-85 \%$ in various courses feeling that laboratories and libraries were well equipped and availed, while as low as 30\% were satisfied with the social amenities like play grounds, college buses, sanitation areas and neatness of compounds. This goes a long way to prove the adage that Indians institution careless about what is not core to academics. This leaves the parents to decide if the choice of an education institution can be based on what is not core.

Assessment of classroom environment revealed that about $70 \%$ were comfortable with the class size and found it conducive for studies. It is only $40 \%$ who were comfortable with the level of students' interaction and many were for the opinion that more interaction should be encouraged to make learning richer. Another $50 \%$ were not comfortable with lecturers' instruction which could be related to the issue of language where only $36 \%$ were comfortable with the language of instruction. This is more of a problem to new students who have yet to get used with the foreign accent and the gestures.

Social Cultural and Environmental factors were the most dissatisfying to the students in Andhra Pradesh State but they felt it was not core to their activities as students. A huge $62 \%$ were un comfortable with religious, because sometimes religious factors can restrict one from getting particular foods especially beef. The high temperatures over the summer period possibly lead to the discomfort of around $62 \%$ of the respondents. On the other side it affects less the studies because by summer all the colleges are on recess. There was $68 \%$ who felt that cultural practices especially noise during the celebrations affected their concentration in their studies. Another $68 \%$ of the respondents confessed to feeling the distances and duration from family played a negative role to their concentration on the studies.

On cost of tuition, the Kenyan universities were in some courses up to five times higher than India. It is only engineering courses which were of the same cost as the Kenyan universities. The other significant cost for students in India is the return air ticket which is roughly sixty thousand $(60,000 /=)$ Kenya Shillings. This assessment takes an assumption that a student does not necessarily have to make home visit for the duration of the course. The upkeep and accommodation cost for both countries is not significantly different but it is in favour of India due to the low cost of living. The respondents were for the opinion that cost of food, transport, medical and housing is lower than it is in Kenya. 
Therefore considering the fact that the content, support facilities and access to other related courses were better for India, then the difference is significant between those studying in India and Kenya. The international exposure is also a big addition to those doing their studies out of the country.

\section{Conclusions And Suggestions}

With the above findings, it is prudent to make the following conclusions and suggestions"

- That the level of female enrolment in India is significantly low and therefore efforts like publicity should be made so that girls can also get the opportunity. It is also wise to note that the social cultural differences are not significant enough to course any restrictive fears.

- That in all manner of assessments, the total cost of university education in India is lower than it is in Kenya. This means Kenyans need to take advantage of this opportunity to get quality university education.

- That the Indian system of university education reduces cost by eliminating non-core cost elements. This should be tried in the Kenyan universities to make them affordable especially to the average and below average citizens.

- That the content is more detailed and deeper, then there is need of a review of the content covered in some university courses in Kenya, more especially in Engineering and computer science. This can as well mean revising the syllabus in the Secondary school level to help prepare students better for university level.

- There is clear evidence from the research that the Kenyan populace is not aware about the cost and quality differences between Indian and Kenyan universities. This therefore calls for publicity initiatives so that Kenya parents can make informed choices.

- A closer look at the courses chosen by Kenyan students reveals a narrow scope. While there are courses like Nursing, Pharmacy, Foreign languages and International Relations on offer none of the sampled students opted for them. Once again this calls for more information to enable choices that guarantee one a marketable and lucrative career in the final analyses.

\section{References And Bibliography}

[1]. Hattangdi, A. and Ghosh, A., (2009), Enhancing the quality and accessibility of higher education through the use of Information and Communication Technology. Strategy Learning: 1-14. Accessed through http://www.iitk.ac.in/

[2]. Birungi, P (2006). Quality Assurance in East Africa: The State of the Art. The Uganda HigherEducation Review. Journal of the Council for Higher Education. Vol3 No.2 pp 10-16.

[3]. University Grants Commission (2008) Higher Education In India- Issues Related To Expansion, Inclusiveness, Quality And Finance, University Grants Commission Bahadur Shah Zafar Marg New Delhi-110 002. Accessed through http://www.ugc.ac.in/

[4]. Boit, J.M and L. C. Kipkoech (2012) Liberalization of Higher Education in Kenya: Challenges and Prospects, International Journal of Academic Research in Progressive Education and Development, April 2012, Vol. 1, No. 2, ISSN: 2226-6348. Accessed through http://www.hrmars.com/

[5]. Christopher Colclough (University of Cambridge), Anuradha De (CORD, New Delhi), and Andrew Webb (University of Cambridge)1 (2010), The Impact of aid on education policy in India and Kenya, Research Consortium on Educational Outcomes \& Poverty-RECOUP, Policy Brief No. 8, October 2010 accessed through http://recoup.educ.cam.ac.uk/publications/pb_8impact_of_aid.pdf

[6]. Eshiwani, G (2009). University Expansion in Eastern Africa: Challenges and Options in Higher Education. Inter-University Council for East Africa (IUCEA). Newsletter Vol. 39 pp 17-22.

[7]. Kaul, S (2006) Higher Education In India: Seizing The Opportunity, Indian Council For Research on International Economic Relations, Working Paper NO.179, May 2006, Core-6a, 4th Floor, India Habitat Centre, Lodi Road, New Delhi-110 003. Accessed Through Http://Www.Icrier.Org/

[8]. Mutisya, K (2010 December 22). How the wrong policies turned public universities into cacophonous markets. Daily Nation, p.13.

[9]. NationMaster Education statistics; India vs $\quad$ Kenya accessed through http://www.nationmaster.com/compare/India/Kenya/Education

[10]. Okwakol, M.J.N (2008). Challenges and Prospects for Quality Assurance in Science and Technology Education in African Countries. The Uganda Higher Education Review. Journal of the National Council for Higher Education, Vol 5 No.2 Pp 17-26.

[11]. Ooro, S (2009) The Quest for Inclusive Higher Education in Kenya: A Vivisection of Concerns, Policies and Reform Initiatives, MAHE INCHER-Kassel, Germany, November 2009 accessed through http://www.ocides.org/wp-content/uploads/2011/02/OoroSarah-Higher-Education-Kenya.pdf

[12]. Parida, S. (2010), Utilization of information and communication technology (ICT) tools by staffand students in universities, Dharwad University of Agricultural Sciences, Dharwad-580005 May, 2010. Accessed through http://etd.uasd.edu

[13]. The Times of India (2013) Indian universities race to attract East African students, IANS Aug12, 2013, 08.22PM IST accessed through http://articles.timesofindia.indiatimes.com/2013-08-12/news/41332052_1_indian-high-commissioner-foreignstudents-higher-education

[14]. Tooley, J (2009) Low cost private schools as part of the solution for education for all, ATDFJournal Volume 5, Issue 1/2, 2009. Accessed through http://www.atdforum.org/

[15]. Tooley, J (2009) The Beautiful Tree: a personal journey into how the world's poorest people areeducating themselves, Penguin, New Delhi, and Cato Institute, 2009. Accessed through www.cato.org/

[16]. UNESCO (2011). School-Based Sexuality Education Programs -A Cost and Cost-Effectiveness Analysis in Six Countries, Published by the United Nations Educational, Scientific and Cultural Organization 7, place de Fontenoy, 75732 Paris 07 SP, France, May 2011, pg 10-12. Accessed through http://www.unesco.org/

[17]. Gudo, C.O, M. A. Olel and I. O Oanda (2011), University Expansion in Kenya and Issues of Quality Education: Challenges and Opportunities, International Journal of Business and Social Science Vol. 2 No. 20; November 2011, http://ijbssnet.com 
Oanda, I.O, F. N. Chege and D. M. Wesonga (2008) Privatization and Private Higher Education in Kenya : Implications for Access, Equity and Knowledge Production, CODESRIA, ISBN: 2-86978-218-7; ISBN 13: 9782869782181; 108 pages, 2008. Accessed through http://www.codesria.org/

[18]. Munene, I.I. (2009) Anticipated developments: East Africa's private universities andprivatisation of public Universities in the global context, Educational Leadership Department College of Education, Africa Education Review, 6: 2, 254 — 268. Accessed through http://oak.ucc.nau.edu/

[19]. Wandiga, S.O (1997) Improving the Managerial Effectiveness of Higher Education Institutions, IIEP Research and Studies Program, UNESCO, 7 - 9 rue Eugène-Delacroix, 75116 Paris. Accessed through http://unesdoc.unesco.org

[20]. World Bank (2000), Higher Education in Developing Countries Peril and Promise, The International Bank for Reconstruction and Development / THE WORLD BANK 1818 H Street, N.W. Washington, D.C. 20433, U.S.A. 